\section{Interaction of CCC and Water Deficit on Wheat Yield}

2-ChLOROETHYLTRIMETHYLAMMONIUM chloride (CCC) shortens wheat straw and is used to lessen losses caused by lodging, but there is good evidence that it sometimes also inereases the yield of wheat in other ways. For example, Humphries, Welbank and Witts ${ }^{\mathbf{r}}$ reported an increase of 5 per cent in the grain yield of 'Phoebus' spring wheat after spraying with either $2.5 \mathrm{lb}$. or $5 \mathrm{lb}$./acre of CCC at the fivo leaf stage, although plants in the untreated plots did not lodge. They tentatively attributed the increase to the better penetration of light through the crop enabling more ear-bearing shoots to survive.

This explanation, however, seemed less likely in view of our experience in 1965 when COC did not increase yield, except perhaps in plots with closely spaced rows (4 in.), although the straw was shortened by CCC as much as in 1964 .

In 1966, increases in yield were obtained in two experi. ments although again lodging in untreated plots was negligible. In the first, $\mathrm{CCC}$ in amounts of $2.5 \mathrm{Ib}$./acre at the five leaf stage was applied to 'Kloka' wheat in the irrigation experiment at the Woburn Experimental Station. A wheat section of this experiment consisted of three blocks of two plots with one plot irrigated in each block. CCC was applied to half plots and four amounts of nitrogen fertilizer $(0 \cdot 4,0 \cdot 8,1 \cdot 2,1 \cdot 6$ cwt./acre) partially confounded with CCC on quarter plots. During a dry period of 2 weeks from May 25, 2 in. of irrigation water was applied. This was beneficial especially in combination with large nitrogen dressings and increased grain yield estimated from sample areas of $2.8 \mathrm{~m}^{2} / \mathrm{plot}$ by $10 \mathrm{cwt}$./acre on plots receiving $\mathbf{1 . 2}$ or $\mathbf{1 . 6}$ cwt. of nitrogen (Table 1 ). CCC had little effect on the yields from the irrigated plots, but it increased yield from the unirrigated plots by 6 cwt. acre. 'These increases in yield were associated with more ear-bearing shoots (estimated from a weighed sub-sample from the area of collection) and greater grain weight/ear (Table 1). Plants treated with CCC seemed to lose fewer shoots than untreated plants during a dry spell in the poriod around ear emergence and so yielded more. More grains on each ear of plants treated with CCC more than offset the smaller weight of 1,000 grains, and so gave a greater grain weight for each ear. The regression of yield on shoot number showed that survival of an additional twenty shoots $/ \mathrm{m}^{2}$ increased grain by $1.9 \mathrm{cwt}$./acre. In an experiment at Rothamsted in 1966 with 'Kloka' wheat given four quantities of fertilizer $(0,0 \cdot 8,1 \cdot 6,2 \cdot 4$ ewt. of nitrogen/ acre), although untreated plots did not lodge, CCC again increased yield by an average of 2 ewt./acre-a result very similar to that obtained in 1964.

Observations that $\mathrm{CCC}$ increases root growth have mostly been made on plants growing in pots ${ }^{2}$, but Hanus ${ }^{3}$

Table 1. SHOOT NUMBERS, GRAIN NUMBER/EAR AND GRAIN WEIGHT/FAR (Mean of 1.2 and 1.6 cwt. of nitrogen/acre)

$$
\text { 'Kloki' }
$$

$\begin{array}{lccccc} & \begin{array}{c}\text { Un- } \\ \text { treated }\end{array} & \text { COC } & \begin{array}{c}\text { Irri- } \\ \text { gated }\end{array} \begin{array}{c}\text { Irri- } \\ \text { gated } \\ \text { and CCO }\end{array} & \begin{array}{c}\text { Stan- } \\ \text { dard } \\ \text { error }\end{array} \\ \begin{array}{l}\text { Yield of grain (85 per cent dry } \\ \text { matter) ewt./acre }\end{array} & 37.5 & 43.5 & 47.8 & 49.6 & 1.67 \\ \begin{array}{l}\text { Far-bearing shoots (millions/ } \\ \text { acre) }\end{array} & 1.91 & 1.99 & 2.07 & 2.10 & 0.07 \\ \begin{array}{l}\text { No. of grains/ear } \\ \text { Dry weight of grains/ear }\end{array} & 23.8 & 28.0 & 28.4 & 30.8 & 1.07 \\ & 0.85 & 0.95 & 1.01 & 1.02 & 0.04\end{array}$

Table 2. DRY WEIGHT OF WHEAT ROOTS $\left(G / \mathrm{M}^{2}\right)$ RECOVERED BY PULINA

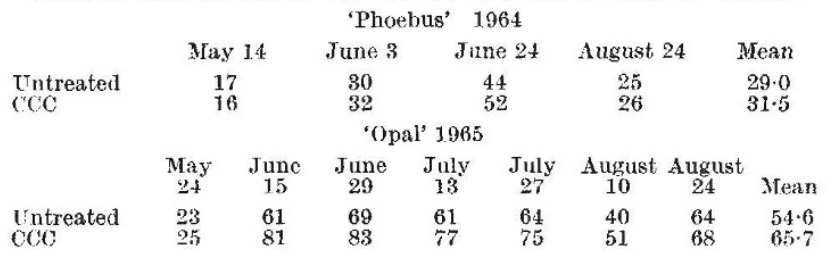

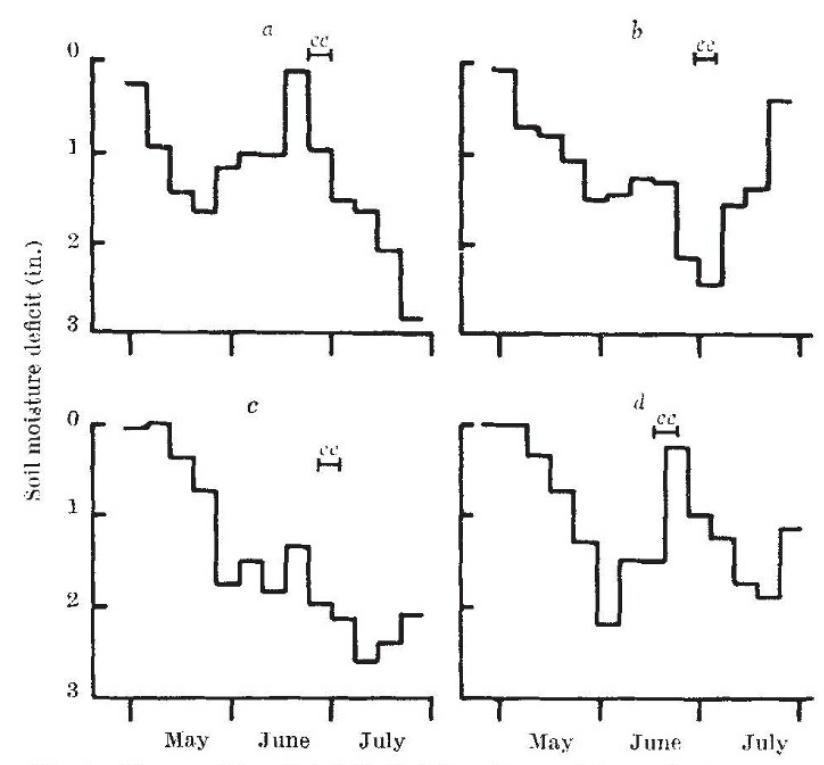

Fig. 1. Mean weekly soil deficits (in.) from May to July; $a$, Rothamsted, 1964; $b$, Rothamsted, 1965; $a$, Rothamsted, 1966: $d$. Woburn, 1966; ee, time of ear ejnergence.

points out that root growth in pots may be restricted and the true effect of $\mathrm{CCC}$ on root growth can be judged only in the fied. We found in both $1964^{3}$ and in 1965 ('Table 2) that the weight of root recovered by hand-pulling, that is roots in the tcp layers of soil, is larger from plants treated with $\mathrm{CCC}$ than from untreated plants. Hanus ${ }^{3}$ showed that whenever it was applied CCC increased root growth at all depths, and he claimed that the larger root systens were associated with larger yield. Many drought-resistant plants are characterized by relatively large root svstems ${ }^{*}$ and CCC may have increased yield in our experiments because it increased the amount of roots and so enabled more shoots to survive dry periods when shoot number was declining, especially about the time cars were cmerging.

Figures supplied by Dr H. J. Penman show that moisture deficits after ear cmergence increased in 1964 and 1966 but decreased in 1965 (when CCC did not increase yield in a normally spaced crop), sce Fig. 1. This suggests that drought is mos's critical near the time of ear emergence and that CCC counteracts it by increasing the size if the root system. 'The greater effect of CCC at Woburn may he because the sandy soil there is more subject to drought than the clay soil at Rothamsted.

\section{E. (.. Humphries \\ P. J. WELBANK \\ F. D. WIILIAMS}

Department of Botany,

Rothamsted Experimental Station.

Harpenden, Herts.

leecived May 30; revised July $4,196 \%$.

${ }^{1}$ Humphries, E. C., Welhank, P. J., and Witts, K. J., Ann. Amp. Biol, 56 $351(1965)$.

${ }^{2}$ Sturm, H., and sung, J., Z. Acker-u. 1'fanzenbau., 120, 232 (1964).

${ }^{3}$ Hanus, H., Z. Acker-u. Pflanzenban., 125, 40 (1967).

+ Williams, R. F., and Shapter, R. E., Austrul. .Y. Biol, sei, 8. 435 (1955).

\section{Selective Phytotoxicity of 2,4-Dichloro 6,} (o-chloroanilino)-s-triazine ('Dyrene') to Circium arvense

WHIL carrying out a fungicide field experimont for the control of Botrytis cinerea on strawberries in an area heavily infested with erecping thistle (Circium arvense), it was noted that approximately 50 per cent of the thistles in certain plots died within 2-3 days of making the first 